\title{
ANALISIS DU PONT SYSTEM DENGAN TIME SERIES APPROACH (TSA) DAN CROSS SECTIONAL APPROACH (CSA) DALAM PENILAIAN KINERJA KEUANGAN PERUSAHAAN (Studi Pada Industri Konstruksi (BUMN) di Indonesia Yang Listing di BEI Tahun 2013-2017)
}

\author{
Nardi Sunardi ${ }^{1)}$ \\ 1) dosen universitas pamulang, email : dosen01030@unpam.ac.id
}

\section{ARTICLES}

JURNAL SEKURITAS

(Saham, Ekonomi, Keuangan dan Investasi )

Vol.1, No.4, Juni 2018

Halaman : 1- 15

(c) LPPM \& Prodi Manajemen

UNIVERSITAS PAMULANG

ISSN (online) : 2581-2777

ISSN (print) : :2581-2696

\section{Keyword :}

Du Pond System, Kinerja

Keuangan Perusahaan,

Perusahaan Konstruksi

JEL. classification :

C31, E50

\section{Contact Author :}

PRODI MANAJEMEN UNPAM

JL.Surya Kencana No.1 Pamulang

Tangerang Selatan - Banten

Telp. (021) 7412566, Fax (021) 7412491

Email :

jurnalfinance.unpam@gmail.com
Penelitian ini bertujuan untuk mengetahu kinerja keuangan perusahaan Industri Konstruksi (BUMN) di Indonesia yang listing di Bursa Efek Indonesia Periode 2013-2017 dengan pendekatan Du Pont System secara Time Series Approach (TSA) dan Cross Sectional Approach (CSA), Hasil penelitian ini menunjukkan bahwa Perusahaan PT.Adhi Karya (Persero) Tbk. rata-rata $2.789 \%$ lebih basar $2.755 \%$ dikatakan berkinerja Baik, PT. PP (Persero) Periode 2013-2017 dengan nilai rata-rata 2.910\% lebih basar dari rata-rata industri dikatakan berkinerja Baik, PT.Wijaya Karya (Persero) Tbk rata-rata $2.645 \%$ lebih basar dari rata-rata industri dikatakan berkinerja Kurang baik, PT. Waskita Karya (Persero) Tbk rata-rata $2.675 \%$ lebih basar dari rata-rata industri sehingga dikatakan berkinerja Kurang baik. menggunakan analisis Return On Investment (ROI) dan Return On Equity (ROE) dengan Time Series Approach (TSA) pada periode 2013 sampai dengan periode 2017 mengalami penurunan dan fluktuatif.Analisis Du Pont System secara Cross Sectional Approach (CSA) pada Industri Perusahaan Konstruksi (BUMN) di Indonesia sebesar $2.755 \%$, Hal ini menunjukkan bahwa secara keseluruhan dikatakan berkinerja BAIK.

This study aims to find out the financial performance of Construction Industry Company (BUMN) in Indonesia listing on Indonesia Stock Exchange Period 2013-2017 with Du Pont System by Time Series Approach (TSA) and Cross Sectional Approach (CSA), The result of this research indicate that Company PT.Adhi Karya (Persero) Tbk. average 2,789\% more bauxite $2.755 \%$ said to be performing Good, PT. PP (Persero) Period 2013-2017 with an average value of $2.910 \%$ more than the industry average is said to be performing Good, PT.Wijaya Karya (Persero) Tbk an average of $2.645 \%$ more than the industry average is said to be underperforming, PT. Waskita Karya (Persero) Tbk averages $2.675 \%$ more than the industry average so it is said to be performing Less good. using Return On Equity (ROI) analysis and Return On Equity (ROE) with Time Series Approach (TSA) in the period of 2013 until the period of 2017 has decreased and fluctuating. Analysis of Du Pont System by Cross Sectional Approach (CSA) in Indonesia of 2.755\%, This indicates that the condition as a whole is said to be performing Good. 


\section{A. Pendahuluan}

Perkembangan dunia dalam perekonomian modern laporan keuangan sudah merupakan media penting dalam proses pengambilan keputusan ekonomi. Laporan keuangan perusahaan lazim diterbitkan secara periodik bisa tahunan, semesteran, triwulan, bulanan, bahkan bisa harian. Laporan keuangan ini sudah menjadi kebutuhan utama pihak-pihak dalam proses pengambilan keputusannya. Laporan keuangan yang terdiri dari 3 jenis: Neraca, Laba-Rugi, dan arus kas sebenarnya memberikan informasi menyeluruh mengenai kondisi perusahaan tetapi karena sifatnya menyeluruh dan general purpose maka kedalaman informasi itu berkurang. Apalagi diketahui sifat-sifat akuntansi itu sendiri mengandung berbagai hal yang menimbulkan keterbatasan dan kelemahannya sendiri. Untuk tidak terjebak dalam masalah ini, di samping agar bisa menggali informasi yang lebih luas, kita mengenal bidang ilmu yang disebut Analisis Laporan Keuangan.

Penilaian kinerja keuangan perusahaan sangat penting bagi perusahaan untuk mengetahui pengalokasian aktiva yang dimiliki secara efektif dan efisien guna mencapai tujuan perusahaan yaitu memperoleh laba maksimal untuk mempertahankan eksistensi perusahaan. Perusahan yang ingin tetap mempertahankan eksistensinya perlu untuk mengadakan evaluasi atau penilaian terhadap kinerja perusahaan, khususnya kinerja keuangan yang menjadi salah satu faktor penunjang perusahaan dalam menjalankan proses bisnis yang semakin kompetitif. Pengukuran kinerja keuangan merupakan salah satu strategi untuk mengelola keuangan agar perusahaan tetap mampu bertahan dan bersaing.

Pendekatan dengan Analisis Keuangan Sistem Dupont merupakan salah satu alat ukur kinerja keuangan yang relevan digunakan untuk melihat sejauh mana efektivitas perusahaan dalam pengembalian atas investasi dilakukan oleh perusahaan atau ROI (Return On Investment). Lianto (2013), mengatakan bahwa perhitungan Return Of Investment (ROI) dan Return Of Equity (ROE) dapat dilakukan melalui analisis Sistem Dupont, yaitu analisis yang menggabungkan antara rasio aktivitas dan profitabilitas.

Objek penelitian dilakukan pada perusahaan go public yang bergerak dibidang Pada Industri Konstruksi (BUMN) di Indonesia yang Listing di Bursa Efek Indonesia Tahun 2013-2017 yaitu PT.Adhi Karya (Persero) Tbk., PT. PP (Persero) Tbk., PT.Wijaya Karya (Persero) Tbk, dan PT. Waskita Karya (Persero) Tbk Berikut.

Sistem $d u$ pont dapat membantu analisis untuk melihat bagaimana keputusankeputusan perusahaan dan aktivitasnya sepanjang periode akuntansi yang diukur dengan ratio-ratio keuangan. Return on equity dengan menggunakan sistem ini analisis dapat mengevaluasi perubahan-perubahan kondisi dan kinerja perusahaan, apakah ada perbaikan atau pemburukan atau kedua-duanya. (Fraser \& ormiston, 2004)

Dari latar belakang tersebut, maka penulis mengambil judul "Analisis Du Pont System dengan Time Series Approach (TSA) dan Cross Sectional Approach (CSA) dalam Penilaian Kinerja Keuangan Perusahaan (Studi Pada Industri Konstruksi (BUMN) di Indonesia yang Listing di Bursa Efek Indonesia Tahun 2013-2017)"

\section{B. Perumusan Masalah}

Berdasarkan latar belakang masalah di atas maka masalah yang akan dibahas dan dicari jawabannya dalam penelitian ini adalah :

1. Bagaimana Penilaian Kinerja Keuangan Perusahaan PT.Adhi Karya (Persero) Tbk yang listing di Bursa Efek Indonesia Tahun 2013-2017 berdasarkan metode Analisis Du Pont System? 
2. Bagaimana Penilaian Kinerja Keuangan Perusahaan PT. PP (Persero) Tbk yang listing di Bursa Efek Indonesia Tahun 2013-2017 berdasarkan metode Analisis Du Pont System?

3. Bagaimana Penilaian Kinerja Keuangan Perusahaan PT.Wijaya Karya (Persero) Tbk yang listing di Bursa Efek Indonesia Tahun 2013-2017 berdasarkan metode Analisis Du Pont System?

4. Bagaimana Penilaian Kinerja Keuangan Perusahaan PT. Waskita Karya (Persero) Tbk yang listing di Bursa Efek Indonesia Tahun 2013-2017 berdasarkan metode Analisis Du Pont System Time Series Approach (TSA) dan Cross Sectional Approach (CSA)?

5. Bagaimana Penilaian Kinerja Keuangan Perusahaan pada Industri Konstruksi (BUMN) di Indonesia yang listing di Bursa Efek Indonesia Tahun 2013-2017 berdasarkan metode Analisis Du Pont System?

\section{Landasan Teori}

\section{Kinerja Keuangan}

Kinerja dapat diartikan sebagai prestasi yang dicapai perusahaan dalam suatu periode tertentu yang mencerminkan tingkat kesehatan perusahaan tersebut" (Winarni dan Sugiyarso, 2005:111). Kinerja keuangan merupakan suatu analisis dalam periode waktu tertentu untuk mengukur suatu gambaran kondisi perusahaan dengan menggunakanaturan pelaksanaan keuangan secara baik dan benar. Menurut Sucipto (2003) mengatakan kinerja keuangan adalah penentuan suatu ukuran tertentu yang dapatmengukur keberhasilan suatu organisasi atau perusahaan dalam menghasilkan laba.Kinerja keuangan dapat diukur dengan cara menganalisis dan mengevaluasi laporan keuangan perusahaan.Sedangkan menurut Dewa (2015) mengatakan kinerja keuangan merupakan hal penting bagi setiap perusahaan di dalam persaingan bisnis untuk mempertahankan kelangsungan perusahaannya.

\section{Analisis Rasio Keuangan}

Analisis rasio keuangan adalah suatu metode analisa untuk mengetahui hubungan dari pos-pos tertentu dalam neraca atau laporan laba rugi secara individu atau kombinasi dari kedua laporan tersebut (Munawir, 2007:37). Analisis rasio keuangan bertujuan untuk:

1. Sebagai proses diagnosis tingkat kesehatan Perusahan

2. Menilai kinerja perusahaan dan Keuangan Perusahaan,

3. Menetahui Nilai Perusahaan

Analisis rasio keuangan digunakan untuk melihat prospek dan risiko perusahaan pada masa yang mendatang. Faktor prospek dalam rasio tersebut akan mempengaruhi harapan investor terhadap perusahaan pada masa-masa mendatang (Hanafi, 2003:75).

Metode Perbandingan Analisis Rasio Keuangan

a. Cross Sectional Approach (CSA)

Yaitu membandingkan rasio-rasio keuangan beberapa perusahaan pada suatu saat yang sama termasuk membandingkan rasio-rasio dengan perusahaan lain yang sejenis atau dapat pula dibandingkan dengan rasio rata-rata industri.

b. Time Series Approach (TSA)

Yaitu membandingkan kinerja keuangan perusahaan dalam beberapa periode mengetahui kondisi masing-masing variabel penelitian dari waktu ke waktu dalam priode tertentu dengan menggunakan analisa rasio keuangan.

c. Combined Analysis Approach (CAA) 


\section{Yaitu gabungan antara Cross Sectional Approach (CSA) dan Time Series Approach (TSA) \\ Du Pont System}

Menurut Weston \& Copeland (1989) Analisis keuangan dengan menggunakan System Du Pont mengabungkan rasio aktivitas dan margin laba terhadap penjualan, dan bagaimana rasio-rasio tersebut saling berinteraksi dalam menetukan profitabilitas dari aktiva.

Metode Du Pont ini memberikan informasi mengenai berbagai faktor yang menyebabkan naik turunnya kinerja keuangan sebuah perusahaan, caranya sebenarnya hampir sama dengan analisis laporan keuangan biasa, namun pendekatannya lebih integrative dengan menggunakan komposisi laporan keuangan sebagai elemen analisisnya, dan mengurangi pos-pos laporan keuangan sampai mendetail, yaitu dengan menganalisis rasio keuangan agar perusahaan dapat mengetahui berbagai faktor yang mempengaruhi efektivitasnya dalam mengelola sumber daya yang perusahaan miliki sehingga perencanaan keuangannya akan lebih baik dimasa yang akan datang.

Pendekatan dengan Analisis Keuangan Sistem Dupont merupakan salah satu alat ukur kinerja keuangan yang relevan digunakan untuk melihat sejauh mana efektivitas perusahaan dalam pengembalian atas investasi yang dilakukan oleh perusahaan atau ROI (Return On Investment).

\section{Kelebihan Du Pont System}

a. Sebagai salah satu teknik analisis keuangan yang sifatnya menyeluruh dan manajemen bisa mengetahui tingkat efisiensi pendayagunaan aktiva.

b. Dapat digunakan untuk mengukur profitabilitas masing-masing produk yang dihasilkan oleh perusahaan sehingga diketahui produk mana yang potensial.

c. Dalam menganalisis laporan keuangan menggunakan pendekatan yang lebih intergrative dan menggunakan laporan keuangan sebagai elemen analisisnya (Harahap, 2004:333).

\section{Kelemahan Du Pont System}

a. ROI suatu perusahaan sulit dibandingkan dengan $\mathrm{ROI}$ perusahaan lain yang sejenis, karena adanya perbedaan praktek akuntansi yang digunakan.

b. Dengan menggunakan ROI saja tidak akan dapat digunakan untuk mengadakan perbandingan antara dua permasalahan atau lebih dengan mendapatkan kesimpulan yang memuaskan (Harahap, 2004:341).

\section{Rasio yang Digunakan Dalam Du Pont System}

a. Rasio Profitabilitas

Rasio profitabilitas mengukur efektivitas manajemen secara keseluruhan melalui keuntungan yang diperoleh dalam hubungannya dengan penjualan maupun investasi (Fahmi, 2012:68).

1) $\mathrm{ROI}$ (Return On Investment) atau ROA (Return On Assets)

ROI menunjukkan kemampuan perusahaan menghasilkan laba dari aktiva yang digunakan (Sartono, 2011:123).

2) ROE (Retun On Equity)

ROE bertujuan mengukur kemampuan perusahaan memperoleh laba yang tersedia bagi pemegang saham perusahaan" (Sartono, 2011:124).

3) 3) Net Profit Margin

Margin laba bersih mengetahui profitabilitas setelah semua pendapatan dan beban, termasuk pos bunga, pajak dipertimbangkan (Fraser dan Ormitson, 2008:237).

b. Rasio Aktivitas

"Rasio aktivitas merupakan rasio yang digunakan untuk mengukur efektivitas perusahaan dalam menggunakan aktiva yang dimilikinya" (Kasmir, 2014:172)

Total Asset Turnover 
Rasio perputaran total aktiva mengukur efisiensi pengelolaan aktiva perusahaan (Brigham dan Houston, 2009:100)

\section{Formula Du Pont System}

Formula Du Pont System dapat diamati, analis dapat mengidentifikasi kekuatan dan kelemahan demikian pula menelusuri sebab-sebab masalah kondisi keuangan dan kinerja perusahaan secara keseluruhan Jika profit margin dikalikan dengan total assets turnover, maka akan menghasilkan ROI (Return On Investment). Jika ROI dikalikan dengan Equity Multiplier, maka akan menghasilkan ROE (Return On Equity). Tiga rasio pertama mengungkap bahwa ROI (laba yang dihasilkan dari investasi keseluruhan dalam aktiva) adalah suatu produk dari margin laba bersih (laba yang dihasilkan dari penjualan) dan perputaran total aktiva (kemampuan perusahaan untuk menghasilkan penjualan dari aktivanya).

Analisis tiga rasio yang tersisa memperlihatkan bagaimana ROE (pengembalian/imbalan keseluruan kepada pemegang saham, pemilik perusahaan) berasal dari produk $\mathrm{ROI}$ dan leverage keuangan (proporsi hutang dalam struktur modal). Penggunaan sistem ini akan dapat mengevaluasi perubahan kinerja perusahaan, apakah dapat menjadi petunjuk peningkatan atau kemerosotan atau kombinasi keduanya. Selanjutnya, evaluasi dapat difokuskan pada bidang-bidang tertentu yang menyumbangkan kepada perubahan-perubahan" (Fraser dan Ormiston, $2008: 253)$.

$$
\begin{aligned}
\text { ROE Du Pond } & =(\text { Net Profit Margin) } \times(\text { Total Asset Turnover) } \times \text { (Multiplier Equity) } \\
& =\frac{\text { Earning After Tax }}{\text { Total Sales }} \times \frac{\text { Total Sales }}{\text { Total Asset }} \times \frac{\text { Total Asset }}{\text { Total Equity }}
\end{aligned}
$$

Variabel Operasional :

Sumber: Atmaja (2008:419)

\begin{tabular}{lcc}
\multicolumn{1}{c}{ Variabel } & Rasio & Measurement \\
\hline Total Aset Turnover & TATO & TATO $=\frac{\text { Sales }}{\text { Total Asset }}$ \\
Net Profit Margin & NPM & NPM $=\frac{\text { EAT }}{\text { Total Sales }}$ \\
Multyplier Equity Ratio & MER & MER $=\frac{\text { Total Asset }}{\text { Total Equity }}$ \\
Return On Invesment Du Pond & ROI-DP & ROI Du Pond $=$ TATO x NPM \\
Return On Equity Du Pond & ROE-DP & ROE Du Pond $=$ ROI Du Pond x MER
\end{tabular}

\section{Metoda Penelitian}

Jenis Penelitian ini merupakan penelitian deskriptif dengan pendekatan kuantitatif.

Fokus penelitian yaitu:

1. Du Pont System

Peneliti hanya melakukan penelitian laporan keuangan dari periode 2013-2017 Perusahaan pada Industri Konstruksi (BUMN) di Indonesia Yang Listing Di Bursa Efek Indonesia yang akan dilakukan perhitungan dalam pendekatan Du Pont System dimana rasio-rasio yang digunakan antara lain:

a. Rasio Profitabilitas

b. Rasio Aktivitas

Melakukan perhitungan Du Pont System dengan menghitung:

a. Return On Investment (ROI)

b. Return On Equity (ROE) dengan Multiplier Equity 
2. Kinerja Keuangan

Setelah melakukan analisis pendekatan Du Pont System dan RI, kemudian membuat kesimpulan dengan menggunakan metode Cross sectional approach dan Time Series Analysis, sehingga dari kesimpulan ini dapat diketahui kinerja keuangan perusahaan.

Populasi dan sampel dalam penelitian ini di Bursa Efek Indonesia periode 20132017 Populasi dalam penelitian ini adalah Perusahaan pada Industri Konstruksi (BUMN) di Indonesia Yang Listing Di Bursa Efek Indonesia periode 2013-2017 dan situs internet www.idx.co.id.

Sampel Penelitian sbb:

\begin{tabular}{ccl}
\hline No. & Kode & \multicolumn{1}{c}{ Perusahaan Konstruksi (BUMN) di Indonesia } \\
\hline 1 & ADHI & PT.Adhi Karya (Persero) Tbk \\
2 & PTPP & PT. PP (Persero) Tbk \\
3 & WIKA & PT.Wijaya Karya (Persero) Tbk \\
4 & WSKT & PT. Waskita Karya (Persero) Tbk \\
\hline
\end{tabular}

\section{Hasil dan Pembahasan}

\section{Analisis dan Interpretasi Data secara Time Series Approach (TSA)}

Kinerja Keuangan Perusahan dari penilaian Analisis dan Interpretasi data secara Time Series Industri Konstruksi (BUMN) di Indonesia. Time Series Approach sebuah metode ini dapat mengetahui kondisi masing-masing variabel penelitian dari waktu ke waktu dalam priode tertentu dilihat dari sbb:

a) Net Profit Margin (NPM) dengan Pendekatan Du Pont System Industri Konstruksi (BUMN) di Indonesia

Kinerja Keuangan Metode Du Pont System Industri Konstruksi (BUMN) di Indonesia dengan pendekatan data secara Time Series sebagai berikut :

Tabel 1 : Rekapitulasi Rasio Keuangan Industri Konstruksi (BUMN) di Indonesia Periode 2013-2017

\begin{tabular}{|c|c|c|c|c|c|c|c|}
\hline $\begin{array}{c}\text { Nama Perusahaan } \\
\text { Konstruksi (BUMN) dl } \\
\text { Indonesia }\end{array}$ & \multicolumn{5}{|c|}{ Net Profit Margin (NPM) } & $\begin{array}{c}\text { Rata- } \\
\text { rata }\end{array}$ & $\begin{array}{c}\text { Kinerja } \\
\text { Keuangan }\end{array}$ \\
\cline { 2 - 8 } & $\mathbf{2 0 1 3}$ & $\mathbf{2 0 1 4}$ & $\mathbf{2 0 1 5}$ & $\mathbf{2 0 1 6}$ & $\mathbf{2 0 1 7}$ & 2.709 & Tidak Baik \\
\hline PT.Adhi Karya (Persero)Tbk & 4.202 & 3.171 & 2.774 & 1.573 & 1.825 & 2.75 \\
\hline PT. PP (Persero) Tbk & 3.389 & 3.641 & 4.413 & 3.687 & 3.164 & 3.659 & Baik \\
\hline PT.Wijaya Karya (Persero) & 4.957 & 4.675 & 3.586 & 3.862 & 2.968 & 4.010 & Baik \\
\hline PT. Waskita Karya (Persero) & 4.187 & 4.079 & 3.456 & 2.951 & 4.292 & 3.793 & Baik \\
\hline RATA-RATA INDUSTRI & $\mathbf{4 . 1 8 4}$ & $\mathbf{3 . 8 9 2}$ & $\mathbf{3 . 5 5 7}$ & $\mathbf{3 . 0 1 8}$ & $\mathbf{3 . 0 6 2}$ & $\mathbf{3 . 5 4 3}$ & Baik \\
\hline
\end{tabular}

Sumber: Data Diolah, 2018

Net Profit Margin (NPM) rata-rata industri Konstruksi (BUMN) di Indonesia periode 2013-2017 mengalami fluktuatif. Periode 2013 sd 2016 mengalami penurunan dari $4.184 \%$ menjadi $3.018 \%$ ini berarti terjadi penurunan sebesar 1.166\%. Periode 2016 dan 2017 nilai NPM sedikit mengalami kenaikan dari 3.018\% menjadi 3.062\% karena persentase kenaikan laba bersih setelah pajak dan penjualan lebih besar dari persentase kenaikan periode 2013. Hal ini berarti perusahaan belum efektif dalam menginvestasikan modalnya dan menunjukkan bahwa perusahaan dapat memberikan kembalian investasi sesuai dengan harapan investornya. 
b) Total Asset Turn Over (TATO) dengan Pendekatan Du Pont System Industri Konstruksi (BUMN) di Indonesia

Kinerja Keuangan Metode Du Pont System Industri Konstruksi (BUMN) di Indonesia dengan pendekatan data secara Time Series sebagai berikut :

Tabel 2 : Rekapitulasi Rasio Keuangan Industri Konstruksi (BUMN) di Indonesia Periode 2013-2017

\begin{tabular}{|c|c|c|c|c|c|c|c|}
\hline \multirow{2}{*}{$\begin{array}{c}\text { Nama Perusahaan } \\
\text { Konstruksi (BUMN) dl } \\
\text { Indonesia }\end{array}$} & \multicolumn{5}{|c|}{ Total Asset Turn Over (TATO } & \multirow{2}{*}{$\begin{array}{l}\text { Rata- } \\
\text { rata }\end{array}$} & \multirow{2}{*}{$\begin{array}{l}\text { Kinerja } \\
\text { Keuangan }\end{array}$} \\
\hline & 2013 & 2014 & 2015 & 2016 & 2017 & & \\
\hline PT.Adhi Karya (Persero)Tbk & 1.008 & 0.827 & 0.560 & 0.552 & 0.535 & 0.697 & Baik \\
\hline PT. PP (Persero) Tbk & 0.939 & 0.850 & 0.742 & 0.527 & 0.389 & 0.690 & Baik \\
\hline PT.Wijaya Karya (Persero) & 0.944 & 0.783 & 0.695 & 0.500 & 0.573 & 0.699 & \\
\hline PT. Waskita Karya (Persero) & 1.102 & 0.820 & 0.467 & 0.387 & 0.462 & 0.648 & Tidak Baik \\
\hline RATA-RATA INDUSTRI & 0.998 & 0.820 & 0.616 & 0.492 & 0.490 & 0.683 & Tidak Baik \\
\hline
\end{tabular}

Total Asset Turn Over (TATO) rata-rata industri Konstruksi (BUMN) di Indonesia periode 2013-2017 mengalami Penurunan. Periode 2013 sd 2017 mengalami penurunan dari 0.998 kali menjadi 0.490 kali ini berarti terjadi penurunan sebesar 0.508 kali. karena persentase penurunan penjualan terhadap total aset. Hal ini berarti perusahaan belum efektif dalam mengoptimalkan aset yang dimiliki untuk mendapatkan retur atau pendapatan usaha.

c) Multiplier Equity Ratio (MER) dengan Pendekatan Du Pont System Industri Konstruksi (BUMN) di Indonesia

Kinerja Keuangan Metode Du Pont System Industri Konstruksi (BUMN) di Indonesia dengan pendekatan data secara Time Series sebagai berikut :

Tabel 3 : Rekapitulasi Rasio Keuangan Industri Konstruksi (BUMN) di Indonesia Periode 2013-2017

\begin{tabular}{|c|c|c|c|c|c|c|c|}
\hline \multirow{2}{*}{$\begin{array}{c}\text { Nama Perusahaan } \\
\text { Konstruksi (BUMN) dl } \\
\text { Indonesia }\end{array}$} & \multicolumn{5}{|c|}{ Multiplier Equity Ratio (MER) } & \multirow{2}{*}{$\begin{array}{l}\text { Rata- } \\
\text { rata }\end{array}$} & \multirow{2}{*}{$\begin{array}{c}\text { Kinerja } \\
\text { Keuangan }\end{array}$} \\
\hline & 2013 & 2014 & 2015 & 2016 & 2017 & & \\
\hline DT.Adhi Karya (Persero) Tbk & 6.278 & 6.374 & 3.247 & 3.682 & & 4.881 & Baik \\
\hline PT. PP (Persero) Tbk & 6.256 & & & & & & \\
\hline PT.Wijaya Karya (Persero) & 3.903 & 3.262 & 3.605 & 2.462 & 3.122 & 3.271 & Tidak Baik \\
\hline PT. Waskita Karya (Persero) & 3.687 & 4.536 & 3.123 & 3.663 & 4.302 & 3.862 & Tidak Baik \\
\hline RATA-RATA INDUSTRI & 5.031 & 5.071 & 3.424 & 3.175 & 3.770 & 4.094 & Baik \\
\hline
\end{tabular}

Multiplier Equity Ratio (MER) rata-rata industri Konstruksi (BUMN) di Indonesia periode 2013-2017 mengalami fluktuatif. Periode 2013 dan 2014 mengalami kenaikan dari $5.031 \%$ menjadi $5.071 \%$ ini berarti terjadi kenaikan sebesar $0.04 \%$. Periode 2014 sd 2014 mengalami penurunan dari 5.071\% menjadi $3.175 \%$ ini berarti terjadi penurunan sebesar 1.896\%. dan Periode 2016 sd 2017 mengalami kenaikan dari $3.175 \%$ menjadi $3.770 \%$ ini berarti terjadi kenaikan sebesar $0.595 \%$. karena persentase kenaikan total aset terhadap total modal. Hal ini berarti perusahaan belum efektif dalam menginvestasikan modalnya dan menunjukkan bahwa perusahaan dapat memberikan kembalian investasi sesuai dengan harapan investornya.

d) Return In Invesment (ROI DuPont) dengan Pendekatan Du Pont System Industri Konstruksi (BUMN) di Indonesia

Kinerja Keuangan Metode Du Pont System Industri Konstruksi (BUMN) di Indonesia dengan pendekatan data secara Time Series sebagai berikut : 
Tabel 4 : Rekapitulasi Rasio Keuangan Industri Konstruksi (BUMN) di Indonesia Periode 2013-2017

\begin{tabular}{|c|c|c|c|c|c|c|c|}
\hline $\begin{array}{c}\text { Nama Perusahaan } \\
\text { Konstruksi (BUMN) dl } \\
\text { Indonesia }\end{array}$ & \multicolumn{5}{|c|}{ ROI Du Pont } & $\begin{array}{c}\text { Rata- } \\
\text { rata }\end{array}$ & $\begin{array}{c}\text { Kinerja } \\
\text { Keuangan }\end{array}$ \\
\cline { 2 - 8 } & $\mathbf{2 0 1 3}$ & $\mathbf{2 0 1 4}$ & $\mathbf{2 0 1 5}$ & $\mathbf{2 0 1 6}$ & $\mathbf{2 0 1 7}$ & & \\
\hline PT.Adhi Karya (Persero)Tbk & 4.236 & 2.624 & 1.554 & 0.868 & 0.976 & 2.052 & Tidak Baik \\
\hline PT. PP (Persero) Tbk & 3.181 & 3.097 & 3.275 & 1.943 & 1.231 & 2.545 & Baik \\
\hline PT.Wijaya Karya (Persero) & 4.678 & 3.662 & 2.492 & 1.930 & 1.701 & 2.893 & Baik \\
\hline PT. Waskita Karya (Persero) & 4.615 & 3.345 & 1.614 & 1.143 & 1.982 & 2.540 & Baik \\
\hline RATA-RATA INDUSTRI & $\mathbf{4 . 1 7 7}$ & $\mathbf{3 . 1 8 2}$ & $\mathbf{2 . 2 3 4}$ & $\mathbf{1 . 4 7 1}$ & $\mathbf{1 . 4 7 3}$ & $\mathbf{2 . 5 0 7}$ & Tidak Baik \\
\hline
\end{tabular}

ROI Du Pont rata-rata industri Konstruksi (BUMN) di Indonesia periode 20132017 mengalami fluktuatif. Periode 2013 sd 2016 mengalami penurunan dari $4.177 \%$ menjadi $1.471 \%$ ini berarti terjadi penurunan sebesar $2.706 \%$. Periode 2016 dan 2017 nilai $\mathrm{ROI}$ sedikit mengalami kenaikan dari $1.471 \%$ menjadi $1.473 \%$ ini berarti terjadi penurunan sebesar $0.002 \%$. karena persentase penurunan laba bersih setelah pajak dan penjualan lebih besar dari persentase kenaikan periode 2016. Hal ini berarti perusahaan belum efektif dalam menginvestasikan modalnya dan menunjukkan bahwa perusahaan dapat memberikan kembalian investasi sesuai dengan harapan investornya..

e) Return On Equity (ROE Du Pont) dengan Pendekatan Du Pont System Industri Konstruksi (BUMN) di Indonesia

Kinerja Keuangan Metode Du Pont System Industri Konstruksi (BUMN) di Indonesia dengan pendekatan data secara Time Series sebagai berikut :

Tabel 5 : Rekapitulasi Rasio Keuangan Industri Konstruksi (BUMN) di Indonesia Periode 2013-2017

\begin{tabular}{|c|c|c|c|c|c|c|c|}
\hline $\begin{array}{c}\text { Nama Perusahaan } \\
\text { Konstruksi (BUMN) dl } \\
\text { Indonesia }\end{array}$ & \multicolumn{5}{|c|}{ ROE Du Pont } & \multirow{2}{*}{$\begin{array}{c}\text { Rata- } \\
\text { rata }\end{array}$} & $\begin{array}{c}\text { Kinerja } \\
\text { Keuangan }\end{array}$ \\
\cline { 2 - 8 } & $\mathbf{2 0 1 3}$ & $\mathbf{2 0 1 4}$ & $\mathbf{2 0 1 5}$ & $\mathbf{2 0 1 6}$ & $\mathbf{2 0 1 7}$ & \\
\hline PT.Adhi Karya (Persero) Tbk & 6.329 & 5.274 & 1.819 & 2.033 & 2.582 & 3.607 & Baik \\
\hline PT. PP (Persero) Tbk & 5.873 & 5.199 & 2.762 & 1.525 & 1.102 & 3.292 & Baik \\
\hline PT.Wijaya Karya (Persero) & 3.683 & 2.556 & 2.505 & 1.230 & 1.789 & 2.352 & Tidak Baik \\
\hline PT. Waskita Karya (Persero) & 4.064 & 3.720 & 1.458 & 1.418 & 1.987 & 2.530 & Tidak Baik \\
\hline RATA-RATA INDUSTRI & $\mathbf{4 . 9 8 7}$ & $\mathbf{4 . 1 8 7}$ & $\mathbf{2 . 1 3 6}$ & $\mathbf{1 . 5 5 1}$ & $\mathbf{1 . 8 6 5}$ & $\mathbf{2 . 9 4 5}$ & Baik \\
\hline
\end{tabular}

ROE Du Pont rata-rata industri Konstruksi (BUMN) di Indonesia periode 20132017 mengalami fluktuatif. Periode 2013 sd 2016 mengalami penurunan dari $4.987 \%$ menjadi $1.551 \%$ ini berarti terjadi penurunan sebesar $3.436 \%$. Periode 2016 dan 2017 nilai ROE sedikit mengalami kenaikan dari $1.551 \%$ menjadi $1.865 \%$ ini berarti terjadi penurunan sebesar $0.314 \%$. karena persentase penurunan laba bersih setelah pajak dan penjualan lebih besar dari persentase kenaikan periode 2016. Hal ini berarti perusahaan belum efektif dalam menginvestasikan modalnya dan menunjukkan bahwa perusahaan dapat memberikan kembalian investasi sesuai dengan harapan investornya.

\section{Analisis dan Interpretasi Data secara Cross Sectional Approach (CSA)}

Cross Sectional Approach sebuah metode untuk membandingkan antara perusahaan yang sejenis dimana metode ini dapat mengetahui kondisi masingmasing perusahaan dilihat dari : 
a) Kinerja Keuangan Metode Du Pont System PT.Adhi Karya (Persero) Tbk.

Kinerja Keuangan Metode Du Pont System Perusahaan PT.Adhi Karya (Persero) Tbk. dengan pendekatan data secara Time Series sbagai berikut :

Tabel 6 : Rekapitulasi Rasio Keuangan Perusahaan PT.Adhi Karya (Persero) Tbk Periode 2013-2017

\begin{tabular}{|c|c|c|c|c|c|c|c|}
\hline \multirow{2}{*}{ Variabel } & \multicolumn{5}{|c|}{ Periode } & $\begin{array}{c}\text { Rata- } \\
\text { rata }\end{array}$ & $\begin{array}{c}\text { Kinerja } \\
\text { Perusahaan }\end{array}$ \\
\cline { 2 - 8 } & $\mathbf{2 0 1 3}$ & $\mathbf{2 0 1 4}$ & $\mathbf{2 0 1 5}$ & $\mathbf{2 0 1 6}$ & $\mathbf{2 0 1 7}$ & \\
\hline Net Profit Margin (NPM) & 4.202 & 3.171 & 2.774 & 1.573 & 1.825 & 2.709 & Tidak Baik \\
\hline Total Asset Turn Over (TATO) & 1.008 & 0.827 & 0.560 & 0.552 & 0.535 & 0.697 & Baik \\
\hline Multiplier Equity Ratio (MER) & 6.278 & 6.374 & 3.247 & 3.682 & 4.827 & 4.881 & Baik \\
\hline ROI Du Pont & 4.236 & 2.624 & 1.554 & 0.868 & 0.976 & 2.052 & Tidak Baik \\
\hline ROE Du Pont & 6.329 & 5.274 & 1.819 & 2.033 & 2.582 & 3.607 & Baik \\
\hline RATA-RATA & 4.410 & 3.654 & 1.991 & 1.741 & 2.149 & $\mathbf{2 . 7 8 9}$ & Baik \\
\hline
\end{tabular}

Berdasarkan tabel Rekapitulasi Rasio Keuangan Perusahaan PT.Adhi Karya (Persero) Tbk Periode 2013-2017 diatas terlihat rasio profitabilitas menunjukkan kondisi perusahaan kurang memuaskan dikarenakan nilai NPM sebesar $2.709 \%$ dan ROI sebesar $2.052 \%$ masih dibawah rata-rata industri $3.543 \%$ artinya kinerja perusahaan dilihat dari profitabilitas tidak baik yang lebih baik adalah MER sebesar $4.881 \%$. dengan demikian perusahaan masih kurang mampu memaksimalkan perolehan laba dalam penjualan, aktiva dan modal. Dilihat dari rasio aktivitas menunjukkan kondisi memuaskan juga dikarenakan nilai TATO sebesar 0.697X diatas nilai rata-rata industri sebesar 4.094X, ini artinya perusahaan sudah menggunakan aktivanya dalam menghaslkan laba, secara keseluruhan kinerja keuangan PT.Adhi Karya (Persero) Tbk Periode 2013-2017 sebesar 2.789 lebih basar dari rata-rata industri sebesar $2.755 \%$ sehingga dikatakan berkinerja baik.

b) Kinerja Keuangan Metode Du Pont System PT. PP (Persero) Tbk

Kinerja Keuangan Metode Du Pont System Perusahaan PT. PP (Persero) Tbk. dengan pendekatan data secara Time Series sbagai berikut :

Tabel 7 : Rekapitulasi Rasio Keuangan Perusahaan PT. PP (Persero) Tbk Periode 2013-2017

\begin{tabular}{|c|c|c|c|c|c|c|c|}
\hline \multirow{2}{*}{ Variabel } & \multicolumn{5}{|c|}{ Periode } & \multirow{2}{*}{$\begin{array}{l}\text { Rata- } \\
\text { rata }\end{array}$} & \multirow{2}{*}{$\begin{array}{c}\text { Kinerja } \\
\text { Perusahaan }\end{array}$} \\
\hline & 2013 & 2014 & 2015 & 2016 & 2017 & & \\
\hline Net Profit Margin (NPM) & 3.389 & 3.641 & 4.413 & 3.687 & 3.164 & 3.659 & Baik \\
\hline Total Asset Turn Over (TATO) & 0.939 & 0.850 & 0.742 & 0.527 & 0.389 & 0.690 & Baik \\
\hline Multiplier Equity Ratio (MER) & 6.256 & 6.113 & 3.722 & 2.893 & 2.830 & 4.363 & Baik \\
\hline ROI Du Pont & 3.181 & 3.097 & 3.275 & 1.943 & 1.231 & 2.545 & Baik \\
\hline ROE Du Pont & 5.873 & 5.199 & 2.762 & 1.525 & 1.102 & 3.292 & Baik \\
\hline RATA-RATA & 3.927 & 3.780 & 2.983 & 2.115 & 1.743 & 2.910 & Baik \\
\hline
\end{tabular}

Sumber: Data Diolah, 2018

Berdasarkan tabel Rekapitulasi Rasio Keuangan Perusahaan PT. PP (Persero) Tbk Periode 2013-2017 diatas terlihat rasio profitabilitas menunjukkan kondisi perusahaan memuaskan dikarenakan nilai NPM sebesar $3.659 \%$, MER sebesar $4.363 \%$. ROI sebesar $2.545 \%$ dan ROE sebesar $3.292 \%$ diatas rata-rata industri artinya kinerja perusahaan dilihat dari profitabilitas dikatakan berkinerja baik dengan demikian perusahaan mampu memaksimalkan perolehan laba dalam penjualan, aktiva dan modal. Dilihat dari rasio aktivitas menunjukkan kondisi memuaskan juga dikarenakan nilai TATO sebesar $0.690 \mathrm{X}$ diatas nilai rata-rata industri sebesar 4.094X, ini artinya perusahaan sudah menggunakan aktivanya dalam menghaslkan 
laba, secara keseluruhan kinerja keuangan PT. PP (Persero) Periode 2013-2017 sebesar $2.910 \%$ lebih basar dari rata-rata industri sebesar $2.755 \%$ sehingga dikatakan berkinerja Baik.

c) Kinerja Keuangan Metode Du Pont System PT.Wijaya Karya (Persero) Tbk Kinerja Keuangan Metode Du Pont System Perusahaan PT.Wijaya Karya (Persero) Tbk dengan pendekatan data secara Time Series sbagai berikut :

Tabel 8 : Rekapitulasi Rasio Keuangan Perusahaan PT.Wijaya Karya (Persero) Tbk Periode 2013-2017

\begin{tabular}{|c|c|c|c|c|c|c|c|}
\hline \multirow{2}{*}{ Variabel } & \multicolumn{5}{|c|}{ Periode } & \multirow{2}{*}{$\begin{array}{l}\text { Rata- } \\
\text { rata }\end{array}$} & \multirow{2}{*}{$\begin{array}{c}\text { Kinerja } \\
\text { Keuangan }\end{array}$} \\
\hline & 2013 & 2014 & 2015 & 2016 & 2017 & & \\
\hline Net Profit Margin (NPM) & 4.957 & 4.675 & 3.586 & 3.862 & 2.968 & 4.010 & Baik \\
\hline Total Asset Turn Over (TATO) & 0.944 & 0.783 & 0.695 & 0.500 & 0.573 & 0.699 & Baik \\
\hline Multiplier Equity Ratio (MER) & 3.903 & 3.262 & 3.605 & 2.462 & 3.122 & 3.271 & Tidak Baik \\
\hline ROI Du Pont & 4.678 & 3.662 & 2.492 & 1.930 & 1.701 & 2.893 & Baik \\
\hline ROE Du Pont & 3.683 & 2.556 & 2.505 & 1.230 & 1.789 & 2.352 & Tidak Baik \\
\hline RATA-RATA & 3.633 & 2.988 & 2.576 & 1.997 & 2.031 & 2.645 & $\begin{array}{c}\text { Kurang } \\
\text { Baik }\end{array}$ \\
\hline
\end{tabular}

Berdasarkan tabel Rekapitulasi Rasio Keuangan Perusahaan PT.Wijaya Karya (Persero) Tbk Periode 2013-2017 diatas terlihat rasio profitabilitas menunjukkan kondisi kinerja perusahaan memuaskan dilihat dari nilai NPM sebesar $4.010 \%$ diatas rata-rata industri $3.543 \%$ dan $\mathrm{ROI}$ sebesar $2.893 \%$ diatas rata-rata industri $2.507 \%$ artinya kinerja perusahaan dilihat dari profitabilitas dikatakan berkinerja baik dengan demikian perusahaan mampu memaksimalkan perolehan laba dalam penjualan, aktiva dan kondisi kinerja perusahaan tidak memuaskan yaitu nilai MER sebesar $3.122 \%$ dan ROE sebesar $2.352 \%$ lebih rendah dari nilai rata-rata industri artinya kinerja perusahaan dikatakan berkinerja tidak baik sehingga perusahaan tidak mampu memaksimalkan perolehan aktiva dan modal. Dilihat dari rasio aktivitas menunjukkan kondisi memuaskan juga dikarenakan nilai TATO sebesar 0.699X diatas nilai rata-rata industri sebesar 4.094X, ini artinya perusahaan sudah menggunakan aktivanya dalam menghasilkan laba, secara keseluruhan kinerja keuangan PT.Wijaya Karya (Persero) Tbk Periode 2013-2017 sebesar 2.645\% lebih basar dari rata-rata industri sebesar $2.755 \%$ sehingga dikatakan berkinerja Kurang baik.

d) Kinerja Keuangan Metode Du Pont System PT. Waskita Karya (Persero) Tbk Kinerja Keuangan Metode Du Pont System Perusahaan PT. Waskita Karya (Persero) Tbk dengan pendekatan data secara Time Series sbagai berikut :

Tabel 9 : Rekapitulasi Rasio Keuangan Perusahaan PT. Waskita Karya (Persero) Tbk Periode 2013-2017

\begin{tabular}{|c|c|c|c|c|c|c|c|}
\hline \multirow{2}{*}{ Variabel } & \multicolumn{5}{|c|}{ Periode } & \multirow{2}{*}{$\begin{array}{l}\text { Rata- } \\
\text { rata }\end{array}$} & \multirow{2}{*}{$\begin{array}{c}\text { Kinerja } \\
\text { Perusahaan }\end{array}$} \\
\hline & 2013 & 2014 & 2015 & 2016 & 2017 & & \\
\hline Net Profit Margin (NPM) & 4.187 & 4.079 & 3.456 & 2.951 & 4.292 & 3.793 & Baik \\
\hline Total Asset Turn Over (TATO) & 1.102 & 0.820 & 0.467 & 0.387 & 0.462 & 0.648 & Tidak Baik \\
\hline Multiplier Equity Ratio (MER) & 3.687 & 4.536 & 3.123 & 3.663 & 4.302 & 3.862 & Tidak Baik \\
\hline ROI Du Pont & 4.615 & 3.345 & 1.614 & 1.143 & 1.982 & 2.540 & Baik \\
\hline ROE Du Pont & 4.064 & 3.720 & 1.458 & 1.418 & 1.987 & 2.530 & Tidak Baik \\
\hline RATA-RATA & 3.531 & 3.300 & 2.024 & 1.912 & 2.605 & 2.675 & $\begin{array}{c}\text { Kurang } \\
\text { Baik }\end{array}$ \\
\hline
\end{tabular}

Sumber: Data Diolah, 2018 
Berdasarkan tabel Rekapitulasi Rasio Keuangan Perusahaan PT. Waskita Karya (Persero) Tbk Periode 2013-2017 diatas terlihat rasio profitabilitas menunjukkan kondisi kinerja perusahaan memuaskan dilihat dari nilai NPM sebesar $3.793 \%$ diatas rata-rata industri $3.543 \%$, dan $\mathrm{ROI}$ sebesar $2.540 \%$ diatas rata-rata industri $2.507 \%$ artinya kinerja perusahaan dilihat dari profitabilitas dikatakan berkinerja baik dengan demikian perusahaan mampu memaksimalkan perolehan laba dalam penjualan, aktiva dan kondisi kinerja perusahaan tidak memuaskan yaitu nilai MER sebesar $3.862 \%$ dan ROE sebesar $2.530 \%$ lebih rendah dari nilai ratarata industri artinya kinerja perusahaan dikatakan berkinerja tidak baik sehingga perusahaan tidak mampu memaksimalkan perolehan aktiva dan modal. Dilihat dari rasio aktivitas menunjukkan kondisi memuaskan juga dikarenakan nilai TATO sebesar 3.862X diatas nilai rata-rata industri sebesar $4.094 \mathrm{X}$, ini artinya perusahaan sudah menggunakan aktivanya dalam menghasilkan laba, secara keseluruhan kinerja keuangan PT. Waskita Karya (Persero) Tbk Periode 2013-2017 sebesar $2.675 \%$ lebih basar dari rata-rata industri sebesar $2.755 \%$ sehingga dikatakan berkinerja Kurang baik.

3. Penilaian Kinerja Keuangan Perusahaan pada Industri Konstruksi (BUMN) di Indonesia yang Listing Di Bursa Efek Indonesia Tahun 2013-2017 berdasarkan metode Analisis Du Pont System.

Hasil metode Analisis Du Pont System Perusahaan pada Industri Konstruksi (BUMN) di Indonesia yang Listing di Bursa Efek Indonesia Tahun 2013-2017 sebagai berikut :

Tabel 10 : Analisis Du Pont System) Perusahaan pada Industri Konstruksi (BUMN) di Indonesia

\begin{tabular}{|c|c|c|c|c|c|c|c|}
\hline \multirow{2}{*}{ Variabel } & \multicolumn{4}{|c|}{ Kode Perusahaan } & \multirow{2}{*}{$\begin{array}{c}\text { Rata- } \\
\text { Rata } \\
\text { Industri }\end{array}$} & \multirow{2}{*}{$\begin{array}{c}\text { Sat } \\
\text {. }\end{array}$} & \multirow{2}{*}{$\begin{array}{l}\text { Kinerja } \\
\text { Industri }\end{array}$} \\
\hline & ADHI & PTPP & WIKA & WSKT & & & \\
\hline Net Propit Margin (NPM) & 2.709 & 3.659 & 4.010 & 3.793 & 3.543 & $\%$ & Baik \\
\hline Total Asset Turn Over (TATO) & 0.697 & 0.690 & 0.699 & 0.648 & 0.683 & $\mathrm{x}$ & $\begin{array}{l}\text { Tidak } \\
\text { Baik }\end{array}$ \\
\hline Multiplier Equity Ratio (MER) & 4.881 & 4.363 & 3.271 & 3.862 & 4.094 & $\%$ & Baik \\
\hline ROI Du Pont & 2.052 & 2.545 & 2.893 & 2.540 & 2.507 & $\%$ & $\begin{array}{l}\text { Tidak } \\
\text { Baik }\end{array}$ \\
\hline ROE Du Pont & 3.607 & 3.292 & 2.352 & 2.530 & 2.945 & $\%$ & Baik \\
\hline RATA-RATA & 2.789 & 2.910 & 2.645 & 2.675 & 2.755 & $\%$ & Baik \\
\hline
\end{tabular}

Sumber: Data diolah (2018)

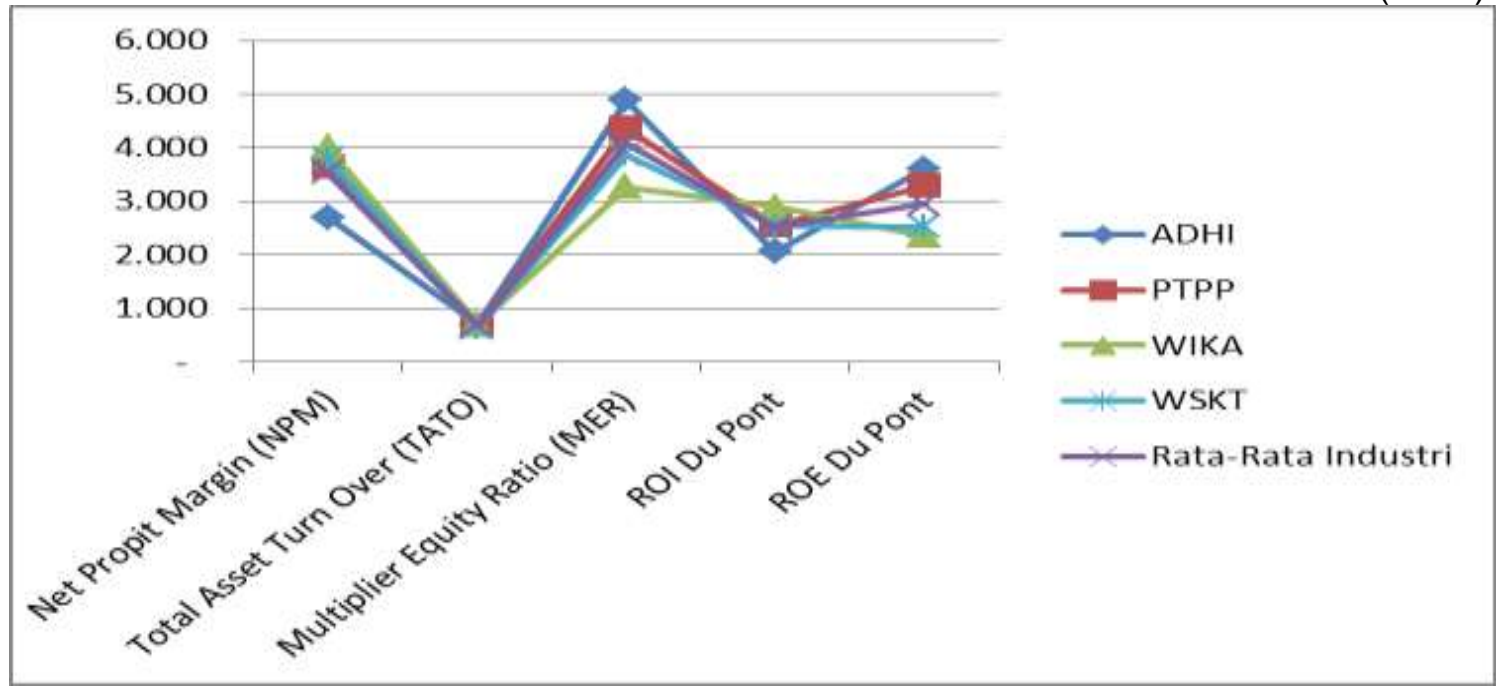


Setelah dilakukan perhitungan terhadap masing-masing variabel masing masing perusahaan dalam empat tahun berturut-turut sehingga dapat diketahui ratarata Analisis Du Pont System pada Industri Perusahaan Konstruksi (BUMN) di Indonesia yang Listing di Bursa Efek Indonesia Tahun 2013-2017 sebesar 2.755, Hal ini menunujukkan bahwa kondisi Industri Perusahaan Konstruksi (BUMN) di Indonesia secara keseluruhan dikatakan berkinerja BAIK.

\section{E. Kesimpulan dan Saran \\ 1. Kesimpulan}

Berdasarkan Analisis Du Pont System dengan Time Series Approach (TSA) dan Cross Sectional Approach (CSA) perusahaan Konstruksi (BUMN) di Indonesia yang Listing di Bursa Efek Indonesia Tahun 2013-2017 sebagai berikut :

a) Analisis Du Pont System untuk penilaian Kinerja Keuangan Perusahaan PT.Adhi Karya (Persero) Tbk. Periode 2013-2017 dengan nilai rata-rata $2.789 \%$ lebih basar dari rata-rata industri sebesar $2.755 \%$ sehingga dikatakan berkinerja Baik

b) Analisis Du Pont System untuk penilaian Kinerja Keuangan Perusahaan PT. PP (Persero) Periode 2013-2017 dengan nilai rata-rata 2.910\% lebih basar dari ratarata industri sebesar $2.755 \%$ sehingga dikatakan berkinerja Baik.

c) Analisis Du Pont System untuk penilaian Kinerja Keuangan Perusahaan PT.Wijaya Karya (Persero) Tbk Periode 2013-2017 dengan nilai rata-rata $2.645 \%$ lebih basar dari rata-rata industri sebesar $2.755 \%$ sehingga dikatakan berkinerja Kurang baik.

d) Analisis Du Pont System untuk penilaian Kinerja Keuangan Perusahaan PT. Waskita Karya (Persero) Tbk Periode 2013-2017 dengan nilai rata-rata $2.675 \%$ lebih basar dari rata-rata industri sebesar $2.755 \%$ sehingga dikatakan berkinerja Kurang baik.

e) Kinerja keuangan perusahaan Konstruksi (BUMN) di Indonesia yang Listing di Bursa Efek Indonesia Tahun 2013-2017 jika menggunakan analisis Return On Investment (ROI) dan Return On Equity (ROE) dengan pendekatan Du Pont System secara Time Series Approach (TSA) pada periode 2013 sampai dengan periode 2017 mengalami penurunan dan fluktuatif. ROI mengalami penurunan disebabkan oleh beban perusahaan, kenaikan beban pokok penjualan dan penggunaan aset yang tidak efektif dan tidak efisien dari tahun ke tahun, sehingga perusahaan masih kurang efektif dan efisien dalam menghasilkan laba atas aset yang dimilikinya. Return On Investment (ROI) dengan pendekatan $D u$ Pont System secara Cross Sectional Approach (CSA) menunjukkan bahwa ratarata $\mathrm{ROI}$ industri yang dihasilkan perusahaan Konstruksi (BUMN) di Indonesia bisa dikatakan masih kurang baik, Kinerja keuangan perusahaan rata-rata Analisis Du Pont System secara cross sectional approach pada Industri Perusahaan Konstruksi (BUMN) di Indonesia yang Listing di Bursa Efek Indonesia Tahun 2013-2017 sebesar 2.755, Hal ini menunjukkan bahwa kondisi Industri Perusahaan Konstruksi (BUMN) di Indonesia secara keseluruhan dikatakan berkinerja BAIK.

\section{Saran}

Adapun saran yang dapat diberikan oleh peneliti atas penelitian yang telah dilakukan adalah sebagai berikut: Perusahaan dalam kategori ini harus lebih memfokuskan pada usaha perbaikan kinerja perusahaan untuk meningkatkan kelima rasio tersebut, misalnya yaitu dengan meningkatkan volume penjualan terhadap persediaan yang ada, sehingga ada pemasukan pada kas perusahaan dari hasil penjualan tersebut. Perusahaan yang berada dalam kondisi rawan bangkrut maka pengelola harus lebih berhati-hati dan harus melakukan perbaikan secepatnya agar tidak mengalami kebangkrutan di periode berikutnya. 


\section{F. Daftar Pustaka}

Atmaja, Lukas Setia. (2008) Teori dan Praktik Manajemen Keuangan. Yogyakarta: Penerbit Andi.

Atmaja, Lukas Setia. (2008). Teori dan Praktik Manajemen Keuangan. Yogyakarta:Penerbit Andi.

Brigham \& Houston. (2010) Dasar - Dasar Manajemen Keuangan (Essentials Of Financial Management). Edisi ke - 11. Salemba Empat. Jakarta. (Diterjemahkan oleh Ali Akbar Yulianto).

Chen, M.C., S.J. Cheng, Y. Hwang. 2005. "An empirical investigation of the relationship between intellectual capital and firms' market value and financial performance". Journal of Intellectual Capital. Vol. 6 N0. 2. hal. 159-176

Darmawi, Herman. 2006, Pasar Finansial dan Lembaga-lembaga Finansial, PT Bumi Aksara, Jakarta.

Daulat Freddy dan Hildawati (2014), Analisis Kinerja Keuangan Perusahaan dengan Menggunakan Metode Du Pont System (Studi pada Perusahaan Food and Beverages yang terdaftar di BEI Periode Tahun 2008-2010), Forum IImiah, Volume 11 Nomor 2, Mei 2014, Universitas Esa Unggul, Jakarta.

Dendawijaya, Lukman, (2005). Manajemen Perbankan, Bogor Jakarta, Ghalia Indonesia.

Eko Prianto dan Dheasy A. (2016), Analisis Du Pont System untuk Menilai Kinerja Keuangan Perusahaan (Studi Pada PT. Mayora Indah Tbk, PT. Delta Djakarta Tbk, dan PT. Indofood Sukses Makmur Tbk Periode Tahun 2010-2015), Fakultas Ekonomika dan Bisnis Universitas Pandanaran

Elita Ika Phrasasty, Kertahadi \& Devi F. Azizah (2015), Analisis Kinerja Keuangan Perusahaan dengan Menggunakan Du Pont System (Studi Pada PT. Semen Indonesia (Persero), Tbk Periode 2009-2013), Jurnal Administrasi Bisnis (JAB), Vol. 2 No. 1 Februari 2015, Universitas Brawijaya Malang.

Endang Fitriana (2016), Pengaruh NPF, CAR, dan EVA terhadap Profitabilitas Perusahaan Perbankan Syariah di BEI, Jurnal Ilmu dan Riset Manajemen : Volume 5, Nomor 4, April 2016, ISSN : 2461-0593, Sekolah Tinggi Ilmu Ekonomi Indonesia (STIESIA) Surabaya.

Erika Augusta, Nardi Sunardi, Leonardus Saiman,\& Abdul Kadim (2018) The Companies Performance With The Du Pont System Approach of Stocks Return and Its Implications on Company Value of Real Estate And Property Sector Listed In IDX, International Journal of Applied Business and Economic Research,. Volume 16, Number 1, 2018, ISSN : 0972-7302

Evi ZN,M. Saifi \& A. Husaini (2015), Analisis Rasio Keuangan Dalam Du Pont System Sebagai Dasar Untuk Mengukur Kinerja Keuangan Perusahaan (Studi Pada PT. Nippon Indosari Corpindo, Tbk yang Terdaftar Pada BEI Periode 2010 - 2012), Fakultas Ilmu Administrasi, Universitas Brawijaya, Malang.

Fraser, Lyn. M dan Ormiston, Aileen. (2008). Memahami Laporan Keuangan. Edisi ketujuh. Diterjemahkan oleh Priyo Darmawan. Jakarta:PT. Indeks

Gujarati, Damodar N .2003, Basic Econometrics, McGraw-Hill, $4^{\text {Th }}$ ed. New York

Husnan, S (2015). Teori Porto folio dan Analisis Investasi edisi Keempat. Yogyakarta: BPFE

Husnan, Suad dan Enny, Pudjiastuti (2006), "Dasar-dasar Manajemen Keuangan", Edisi Lima, Yogyakarta : UPP STIM YKPN

Husnan, Suad. Manajemen Keuangan (2008): Teori dan Penerapan Buku 1, Edisi 4, BPFE Yogyakarta

Ikatan Akuntan Indonesia. 2010. Pernyataan Standar Akuntansi Keuangan No. 19, Per 7 Maret 2016. 
Iswati, Sri. (2007). Memprediksi Kinerja Keuangan Dengan Modal Intelektual Pada Perusahaan Perbankan Terbuka Di Bursa Efek Jakarta. Ekuitas .Vol 2, No 11: 159174

Karim, Adiwarman. 2010. Bank Islam Analisis Fiqih dan Keuangan Edisi Keempat. Rajawali Press, Jakarta

Kasmir. 2012. Bank dan Lembaga Keuangan Lainnya. PT Raja Grafindo Persada

Kasmir. 2014. Analisis Laporan Keuangan. Jakarta:PT. Raja Grafindo Persada.

Katsir, Ibnu, 2003, Tafsir Ibnu Katsir, Jilid 1-7, Pustaka Imam Syafi'I, Bogor

Landora'i DS, R. Rengkung \& E.Tangkere (2014), Pengukuran Kinerja Keuangan Berdasarkan Roi (Return On Investment) dengan Pendekatan Sistem Dupont pada PT. Tropica Cocoprima), Agri-SosioEkonomiUnsrat, ISSN 1907-4298, Volume 13 Nomor 1 Januari : 89 - 98.

Lianto D. (2013) Penilaian Kinerja Keuangan Perusahaan Menggunakan Analisis Du Pont. Jurnal. Universitas Ma Chung.

Limpaphayom, Piman, dan Siraphat Polwitoon, (2004), "Bank Relationship and Firm Performance: Evidence from Thailand before The Asian Financial Crisis," Journal of Bussiness Finance and Accounting, 2004

Machmud, Amir dan Rukmana. 2010. Bank Syariah Teori, Kebijakan, dan Studi Empiris di Indonesia. Jakarta: Erlangga.

Mamduh, M. Hanafi (2003) Analisis Laporan Keuangan. Edisi Revisi, Cetakan Pertama, Yogyakarta: UPP AMP YKPN.

Millward Brown, 2015, 2015 BrandZ Top 100 Global Brands, Per December 2015,http://www.millwardbrown.com/brandz/top-globalbrands/2015/introduction

Muharam, Harjum dan Pusvitasari. 2007. Analisis Perbandingan Efisiensi Bank Syariah di Indonesia dengan Metode Data Envelopment Analysis. Jurnal Ekonomi dan Bisnis Islam. Vol.2 No.3 Hal: 80-116

Munawir, S. (2007) Analisa Laporan Keuangan. Edisi Keempat, Cetakan Keempat belas, Yogyakarta: Liberty.

Nachrowi, Djalal Nachrowi, Hardius Usman. 2006. Pendekatan Populer dan Praktis Ekonometruka untuk Analisis Ekonomi dan Keuangan, Lembaga Penerbit Universitas Indonesia, Jakarta

Nardi Sunardi (2017) Determinan Kebijakan Utang Serta Implikasinya terhadap Kinerja Perusahaan (Perusahaan yang tergabung dalam indeks LQ.45 yang terdaftar di Bursa Efek Indonesia Tahun 2011- 2015) Jurnal Sekuritas, Vol. 1, No.1 / September 2017 Universitas Pamulang.

Nardi Sunardi, Aceng Abdul Hamid, Lativa, Abdul Kadim, Natanael Tulus (2018) Determinant Of Cost Efficiency And It's Implications For Companies Performance Incorporated In The Lq.45 Index Listing In Idx For The Period of 2011-2016, International Journal of Applied Business and Economic Research,.Volume 16, Number 1, 2018, ISSN : 0972-7302

Nataly, Daisy, 2011, "Knowledge Management", Makalah pada MB IPB, Bogor 18 Maret 2011.

Nuraini,Topowijono dan F.Yaningwati (2015), Penilaian Kinerja Keuangan Perusahaan Menggunakan Analisis Return On Investment (ROI) Dengan Pendekatan Du Pont System Dan Residual Income (RI) (Studi Pada Perusahaan Kosmetik Dan Keperluan Rumah Tangga Yang Listing Di Bursa Efek Indonesia Tahun 2011-2013), Jurnal Administrasi Bisnis (JAB)|Vol. 26 No. 2 September 2015.

Organization for Economic Co-operation and Development (OECD). 1999. International Symposium on Measuring and Reporting Intellectual Capital, Experience, Issues and Prospects. Amsterdam, 9-11 June 1999.

Otoritas Jasa Keuangan, 2015, Roadmap Perbankan Syariah Indonesia 2015-2019, Departemen Perbankan Syariah OJK, Jakarta 
Pangestika, Styfanda, 2015, Analisis Estimasi Moel Regresi Data Panel Dengan Pendekatan Common Effect Model (CEM), Fixed Effect Model (FEM), dan Random Effect Model (REM), Skripsi Fakultas MIPA Universitas Negeri Semarang, tidak dipublikasikan

Peraturan Perundang-undangan, 1992, Undang-undang Republik Indonesia Tahun 1992 Tentang Perbankan, DPR-RI, Jakarta

Petty, P. and J. Guthrie. 2000. "Intellectual capital literature review: measurement, reporting and management". Journal of Intellectual Capital. Vol. 1 No. 2. hal. 155-75.

Riahi-Belkaoiu, A. 2003. "Intellectual capital and firm performance of US multinational firms: a study of the resource-based and stakeholder views". Journal of Intellectual Capital. Vol. 4 No. 2. hal. 215-226.

Riyadi Slamet, 2006. Banking Assets and Liability Management (Edisi Ketiga). Jakarta: Lembaga Penerbit Fakultas Ekonomi Universitas Indonesia, 2006.

Rose, Peter S and Sylvia C Hudgins (2010) Bank Management and Financial Services. New York : Mc Grow Hill

Salman, R. T., Mansor, M., Babatunde, A. D., Tayib, M. 2012, Impact of Intellectual Capital on Return on Asset in Nigerian Manufacturing Companies, Interdisciplinary Journal of Research in Business, Vol. 2 No. 4, hal. 21-30.

Soetrisno, Agustinus, Lina, 2014, The Influence of Intellectual Capital Components Towards The Company Performance, Jurnal Manajemen Universitas Pelita Harapan, Vol. 14, No1, Hal. 125-140

Subandi dan Ghozali, Imam. 2013. Determinan Efisiensi dan Dampaknya Terhadap Kinerja Profitabilitas Industri Perbankan Di Indonesia. Jurnal Keuangan dan Perbankan Vol. 17 (1) Januari.

Sufian, Fadzlan and Royfaizal Razali Chong. 2008. Determinants of Bank Profitability in A Developing Economy: Empirical Evidence From The Philippines. Asian Academy of Management Journal of Accounting and Finance, 4(2): 91112.

Sumitro, Warkum. 2004, Asas-asas Perbankan Islam dan Lembaga Terkait, Rajawali Press, Jakarta

Sunann Ibn Majah kitab Al-Muqoddimah bab Fadl Al-Ulama wa al-hasts ala talab al-ilm no,224. (Abu Abdillah Muhammad ibn Yazid al-Qazwini, sunan Ibn Majah, Beirut:Dar al-Fikr, 1995, Jilid 1, hal. 81)

Tan, H.P., D. Plowman, P. Hancock. 2007. "Intellectual capital and financial returns of companies". Journal of Intellectual Capital. Vol. 8 No. 1. hal. 76-95.

Taswan. 2010. Manajemen Perbankan, Konsep, Teknik, dan Aplikasi. Edisi Kedua. Yogyakarta : UPP STIM YKPN.

Usman, Bahtiar. 2003. Analisis Rasio Keuangan dalam Memprediksi Perubahan Laba pada Bank-Bank di Indonesia. Media Riset \& Manajemen. Vol.3 (1)

White, D. Steven, Gunasekaran, Angappa. Ariguzo, Godwin C. 2013, "The Structural Components of a Knowledge-based Economy", Int. J. Business Innovation and Research, Vol. 7, No. 4, hal. 504-518

Winarni, F dan Sugiyarso, G. (2005). Manajemen Keuangan. Yogyakarta: Liberty.

Zuhal. 2010. Knowledge \& Inovation sebagai Platform Kekuatan Daya Saing. PT. Gramedia Pustaka Utama, Jakarta 